\title{
Genetic variability of Apolipoprotein E in different populations from Venezuela
}

\author{
M.T. Fernández-Mestre, Castro Yehirobi, S. Montagnani, O. Balbas and Z. Layrisse \\ Laboratorio de Fisiopatología, Instituto Venezolano de Investigaciones Científicas, Caracas, Venezuela
}

\begin{abstract}
The genetic variation at the Apolipoprotein E locus (APOE) is an important determinant of plasma lipids and has been implicated in various human pathological conditions. The objective of the present study was to estimate the distribution of APOE alleles in five Venezuelan communities: two Amerindian tribes (Bari and Yucpa), one Negroid population from Curiepe, one Caucasoid population from Colonia Tovar and the mestizo urban population living in Caracas. The APOE*3 allele was the most common allele in all populations studied. However, a significant increase in the APOE*2 allele frequency in the Mestizo (18.96\%) and Negroid (16.25\%) populations was found. Similar to results reported in other Native American populations we have found that the APOE*2 allele is completely absent in the Bari and Yucpa Amerindians. Frequencies found in the Colonia Tovar population are in agreement with those reported in the population of Germany, indicating a high degree of relatedness. The results support the notion that the distribution of the APOE alleles shows ethnic variability.
\end{abstract}

Keywords: Venezuelan populations, APOE, polymorphism

\section{Introduction}

Apolipoprotein $\mathrm{E}(\mathrm{APOE}=$ gene $; \mathrm{apoE}=$ protein $)$ is a component of the very low and high-density lipoproteins [18] and plays an important role in lipoprotein metabolism [19]. The APOE locus shows a genetic polymorphism determined by three common alleles APOE*2 APOE*3, APOE*4 [36] and the product of each allele differs in several functional properties [7]. The APOE genetic variability has been found to be implicated in various human pathological conditions, such as atherosclerosis and cardiovascular disease, noninsulin-dependent diabetes mellitus and Alzheimer disease [7,14,17,33-35]. Due to its medical and anthropological significance the APOE polymorphism has been also studied in various populations worldwide $[1,10]$.

The objective of the present study was, first, to report the distribution of APOE alleles in five Venezuelan

\footnotetext{
*Corresponding author: Zulay Layrisse, Laboratorio de Fisiopatología, Centro de Medicina Experimental "Miguel Layrisse", Instituto Venezolano de Investigaciones Cienúficas, Kilómetro 11 Carretera Panamericana, Apdo. 21827, Caracas 1020a, Venezuela. Fax: +58 212 5041086; E-mail: zlayriss@medicina.ivic.ve.
}

population groups: two Amerindian communities of the Perija Range (Bari and Yucpa), one Negroid population from Curiepe (Miranda state), one Caucasoid population from Colonia Tovar (Aragua state) and the mestizo urban population living in Caracas. Our second objective was to compare our results with findings of the APOE allele frequency in other populations. This study is a first step to investigate an association between APOE polymorphism and cardiovascular disease, and Alzheimer's disease, with the purpose to understand the role of APOE in the development of these multifactorial diseases.

\section{Materials and methods}

\subsection{Subjects}

The Venezuelan population groups studied include the following:

a- Amerindian population. Thirty-one healthy unrelated adult Yucpa and forty-one Bari Ameridians. Both tribes inhabit the Perija Mountain Range, on the border between Venezuela and 
Colombia $\left(9^{\circ} 50^{\prime} \mathrm{N}\right.$ and $\left.7250^{\prime}-735^{\prime} \mathrm{E}\right)$ [16]. The Yucpa inhabiting the northern section of the Perija Range, are classified as "Carib" because they speak a language of Cariban affiliation, and the Bari in the southern section, are classified as Chibchan according to their language.

b- Caucasoid population. Forty unrelated individuals living in Colonia Tovar, a rural town located in the northeast of the Aragua state, Venezuela $\left(67.18^{\circ} \mathrm{W} 10.25^{\circ} \mathrm{N}\right)$. This town was founded in 1843 by 390 immigrants from South-Western Germany. They remained in almost complete geographic isolation for 115 years, until roads were built to connect the town with Caracas and other places [28].

c- Negroid population. Forty unrelated individuals of the Afro-Venezuelan community of Curiepe (Miranda state), a village located just two hours east of Caracas.

d- Venezuelan mestizo population. Eighty-seven unrelated mestizo individuals from different regions of the country, mainly inhabitants of Caracas. A Venezuelan Mestizo is defined as someone born in Venezuela who is descendant of the indigenous inhabitants of the country and of individuals of Caucasian origin, mainly Spanish.

\subsection{APOE polymorphism analysis}

Genomic DNA was extracted from peripheral blood by salt precipitation [21]. DNA was amplified by polymerase chain reaction (PCR) using the oligonucleotide primers described by Emi et al. [8]. The APOE polymorphism was analyzed by PCR-RFLP (Restriction Fragment Length Polymorphism). Amplicons were digested with the enzyme Hha I using conditions described by Hixson \& Vernier [12] and the manufacturer's protocol (GIBCO, BRL). The fragments were visualized by electrophoresis in $4 \%$ agarose gels treated with ethidium bromide, using a 10-bp ladder to score the band sizes.

\subsection{Statistical analysis}

Allele and genotype frequencies were obtained by direct counting. A X2 test was used to verify whether the observed genotype frequencies agreed with those expected under the hypothesis of Hardy-Weinberg. Differences in allele frequencies between groups were analyzed using a contingency chi-square test. Gene diversity analysis was made using the DISPAN pro- gram [27]. The following statistics were calculated: HT (genic diversity in the total population), HS (average gene diversity within populations) and GST (gene differentiation between populations relative to the gene diversity in the total population) [23-25]. Since the GST value is influenced by the number of subpopulations studied, an appropriate correction was made, leading to the statistic GST' [25]. The genetic distance employed was the DA distance modified by CavalliSforza [26].

\section{Results and discussion}

The distribution of the APOE allele and genotype frequencies in the five Venezuelan populations is shown in Table 1. Three common alleles, APOE*2, APOE*3 and $\mathrm{APOE}^{*} 4$, are present in the Colonia Tovar, Curiepe and Mestizo populations. Five APOE genotypes were identified in the Venezuelan mestizos: E2/3 (31\%), $\mathrm{E} 2 / 4(7 \%), \mathrm{E} 3 / 3(53 \%), \mathrm{E} 3 / 4(6 \%)$ and $\mathrm{E} 4 / 4(3 \%)$ and four in the Caucasoid and Negroid populations: Colonia Tovar: E2/3 (7.5\%), E3/E3 (65\%), E3/4 (25\%) and E4/4 (2.5\%); Curiepe: E2/3 (20\%), E2/E4 (12.5\%), $\mathrm{E} 3 / 3(62.5 \%)$ and $\mathrm{E} 3 / 4(5 \%)$.

As can be observed, the APOE*3 allele was the most common allele in all populations studied. However, there is a significant increase in the APOE*2 allele frequency in the Mestizo (18.96\%) and Negroid (16.25\%) populations, higher to the frequency reported in the Papuans (14.5\%), which has been considered the highest frequency reported worldwide [13]. These results contrast with a study realized in Venezuela reporting a lower $\mathrm{APOE}^{*} 2$ frequency in the urban population of Maracaibo city [22], and with results reported in Africans of the Caribbean islands of Trinidad and $\mathrm{Cu}-$ racao [3]. Besides differences due to sample size and methodology, contrasting results could be explained if ethnic admixture differences in Venezuela and the Caribbean islands are considered. The Venezuelan Mestizo population derives from different degrees of admixture of native Amerindians, European Caucasoid and/or Negroid migrants brought mainly from Western Africa. The rate of admixture varies regionally and previous genetic studies have shown frequency differences between the populations of Maracaibo and Caracas [29]. On the other hand, populations derived from West African descendants living in Venezuela have also been subjected to European and Amerindian admixture [2] and lack the South Asian ancestry component present in the Caribbean islands of Trinidad and To- 
Table 1

Distribution of APOE allele and genotype frequencies in Amerindians, Caucasians, Blacks and Venezuelan mestizo populations

\begin{tabular}{|c|c|c|c|c|c|c|}
\hline \multirow[t]{2}{*}{ Population } & \multirow[b]{2}{*}{$\mathrm{n}$} & \multicolumn{5}{|c|}{ Allele frequency } \\
\hline & & $E^{*} 2$ & & $\mathrm{E}^{*} 3$ & & $\mathrm{E}^{*} 4$ \\
\hline \multicolumn{7}{|l|}{ Amerindians } \\
\hline Yucpa & 31 & 0.000 & & 1.000 & & 0.000 \\
\hline Bari & 41 & 0.000 & & 0.870 & & 0.120 \\
\hline \multicolumn{7}{|l|}{ Caucasians } \\
\hline $\begin{array}{l}\text { Negroid } \\
\text { Curiepe } \\
\text { Mestizos }\end{array}$ & $\begin{array}{l}40 \\
87\end{array}$ & $\begin{array}{l}0.162 \\
0.189\end{array}$ & & $\begin{array}{l}0.750 \\
0.713\end{array}$ & & $\begin{array}{l}0.087 \\
0.097\end{array}$ \\
\hline \multirow{2}{*}{ Mestizos } & & \multicolumn{5}{|c|}{ Genotype frequency } \\
\hline & $\mathrm{n}$ & $\mathrm{E} 2 / 3$ & $\mathrm{E} 2 / 4$ & $\mathrm{E} 3 / 3$ & $\mathrm{E} 3 / 4$ & $\mathrm{E} 4 / 4$ \\
\hline \multicolumn{7}{|l|}{ Amerindians } \\
\hline Yucpa & 31 & 0.000 & 0.000 & 1.000 & 0.000 & 0.000 \\
\hline Bari & 41 & 0.000 & 0.000 & 0.756 & 0.243 & 0.000 \\
\hline $\begin{array}{l}\text { Caucasians } \\
\text { Colonia Tovar }\end{array}$ & 40 & 0.075 & 0.000 & 0.650 & 0.250 & 0.025 \\
\hline Negroid Curiepe & 40 & 0.200 & 0.125 & 0.625 & 0.050 & 0.000 \\
\hline Mestizos & 87 & 0.310 & 0.068 & 0.528 & 0.057 & 0.034 \\
\hline
\end{tabular}

Table 2

Gene diversity analysis of the APOE genetic system

\begin{tabular}{lcc}
\hline Population & $\begin{array}{c}\text { Gene diversity } \\
\pm \text { standard error }\end{array}$ & $\mathrm{N}^{\circ}$ of individuals \\
\hline Mestizo & $0.4492 \pm 0.0383$ & 87 \\
Curiepe & $0.4085 \pm 0.0598$ & 40 \\
Colonia Tovar & $0.3199 \pm 0.0601$ & 40 \\
Bari & $0.2168 \pm 0.0548$ & 41 \\
Yucpa & $0.0000 \pm 0.0000$ & 31 \\
Total $\mathrm{H}_{\mathrm{T}}$ & 0.302 & \\
HS (Intrapopulational) & 0.284 & \\
GST'(\%) (Interpopulational) & 6.01 & \\
\hline
\end{tabular}

$\mathrm{H}_{\mathrm{T}}$ : genic diversity in the total population; $\mathrm{H}_{\mathrm{S}}$ : average gene diversity within populations; $\mathrm{G}_{\mathrm{ST}^{\prime}}$ : $\mathrm{G}_{\mathrm{ST}}$ value corrected.

bago. Frequency differences are of interest since individuals with at least one $\mathrm{APOE}^{*} 2$ allele tend to have lower levels of total and LDL cholesterol, so this allele has been considered to protect against coronary artery disease [7] and Alzheimer's disease [5,14,17,35] and to promote human longevity [32].

Among Caucasian populations there is significant variation in allele frequencies [10], but the frequencies found in the Colonia Tovar population are in agreement with the frequencies reported in the population of Germany [37].

Considering the Amerindian populations, only APOE*3 and $\mathrm{APOE}^{*} 4$ alleles were observed among the Bari with only two genotypes [E3/E3 (76\%) and E3/E4 (24\%)] rather than the expected three genotypes [E3/E3, E3/E4 and E4/E4]. In the Yucpa, the APOE gene is monomorphic, in agreement with results re- ported among the Yuco of Colombia [13]. In both Amerindian populations the APOE*2 allele is completely absent. This finding is similar to results reported in other Native American populations [1,6,9,20, $31]$ and support the hypothesis that APOE*2 was absent in the groups who inhabited the Americas in prehistoric times [11]. The frequency of $\mathrm{APOE}^{*} 2$ observed in North American Indians [15] and in two South American tribes (Wai-Wai and Mataco) might be explained by admixture with non-Indian populations [1].

In two groups, Colonia Tovar and Bari, the genotypes observed were in agreement with those expected under Hardy-Weinberg equilibrium. In contrast, the APOE allele frequencies in the Mestizo and Curiepe populations were not in Hardy-Weinberg equilibrium. The deviations from this equilibrium are likely due to recent admixture in these populations. The Hardy-Weinberg 
Table 3

Genetic distances (DA) base in the APOE locus between five Venezuelan populations and other populations

\begin{tabular}{|c|c|c|c|c|c|c|c|c|c|c|c|c|c|}
\hline Populations & 1 & 2 & 3 & 4 & 5 & 6 & 7 & 8 & 9 & 10 & 11 & 12 & 13 \\
\hline $\begin{array}{l}\text { 1. Mestizo: } \\
\text { Venezuela }\end{array}$ & 0.00000 & 0.00122 & 0.02376 & 0.03341 & 0.04270 & 0.01423 & 0.02172 & 0.01480 & 0.03431 & 0.02745 & 0.06255 & 0.22207 & 0.06105 \\
\hline 2. Curiepe & 00122 & 0.00000 & 0.01616 & 0.02299 & 0.02933 & 0.00924 & 0.01309 & 0.00777 & 0.02279 & 0.01724 & 0.05928 & 0.22686 & 0.05513 \\
\hline $\begin{array}{l}\text { 3. Colonia } \\
\text { Tovar }\end{array}$ & 02376 & 0.01616 & 0.00000 & 0.00163 & 0.01800 & 0.00142 & 0.00213 & 0.00343 & 0.00517 & 0.00440 & 0.02628 & 0.16611 & 0.01860 \\
\hline 4. Bari & 33341 & 0.02299 & 0.00163 & 0.00000 & 0.01104 & 0.00570 & 0.00168 & 0.00442 & 0.00155 & 0.00200 & 0.03589 & 0.18984 & 0.02497 \\
\hline 5. Yucpa & 04270 & 0.02933 & 0.01800 & 0.01104 & 0.00000 & 0.02324 & 0.00831 & 0.01010 & 0.00430 & 0.00459 & 0.08813 & 0.30782 & 0.07042 \\
\hline $\begin{array}{l}\text { 6. Caucasians: } \\
\text { Germany }\end{array}$ & 01423 & 0.00924 & 0.00142 & 0.00570 & 0.02324 & 0.00000 & 0.00378 & 0.00318 & 0.00967 & 0.00743 & 0.02628 & 0.16323 & 0.02091 \\
\hline $\begin{array}{l}\text { 7. Caucasians: } \\
\text { Spain }\end{array}$ & 0.02172 & 0.01309 & 0.00213 & 0.00168 & 0.00831 & 0.00378 & 0.00000 & 0.00070 & 0.00159 & 0.00061 & 0.04369 & 0.21005 & 0.03338 \\
\hline $\begin{array}{l}\text { 8. Caucasians: } \\
\text { Italy }\end{array}$ & 0.01480 & 0.00777 & 0.00343 & 0.00442 & 0.01010 & 0.00318 & 0.00070 & 0.00000 & 0.00397 & 0.00196 & 0.04675 & 0.21588 & 0.03757 \\
\hline $\begin{array}{l}\text { 9. Mestizo: } \\
\text { Mexico }\end{array}$ & 0.03431 & 0.02279 & 0.00517 & 0.00155 & 0.00430 & 0.00967 & 0.00159 & 0.00397 & 0.00000 & 0.00039 & 0.05262 & 0.22997 & 0.03923 \\
\hline $\begin{array}{l}\text { 10. Mestizo: } \\
\text { Colombia }\end{array}$ & 0.02745 & 0.01724 & 0.00440 & 0.00200 & 0.00459 & 0.00743 & 0.00061 & 0.00196 & 0.00039 & 0.00000 & 0.05228 & 0.23016 & 0.03992 \\
\hline $\begin{array}{l}\text { 11. African: } \\
\text { Nigeria }\end{array}$ & 0.06255 & 0.05928 & 0.02628 & 0.03589 & 0.08813 & 0.02628 & 0.04369 & 0.04675 & 0.05262 & 0.05228 & 0.00000 & 0.05627 & 0.00152 \\
\hline $\begin{array}{l}\text { 12. Native: } \\
\text { Wai-Wai }\end{array}$ & 0.22207 & 0.22686 & 0.16611 & 0.18984 & 0.30782 & 0.16323 & 0.21005 & 0.21588 & 0.22997 & 0.23016 & 0.05627 & 0.00000 & 0.07193 \\
\hline $\begin{array}{l}\text { 13. Native: } \\
\text { Cayapa }\end{array}$ & 0.06105 & 0.05513 & 0.01860 & 0.02497 & 0.07042 & 0.02091 & 0.03338 & 0.03757 & 0.03923 & 0.03992 & 0.00152 & 0.07193 & 0.00000 \\
\hline
\end{tabular}

test was not done in the Yucpa because the APOE locus was found to be monomorphic.

Results of the single-locus and gene diversity analysis considering the five populations are shown in Table 2. Total diversity $\left(\mathrm{H}_{\mathrm{T}}\right)$ for the mestizos from Caracas $(45 \%)$ is similar to that present in Curiepe (41\%) and higher from that of Colonia Tovar $(32 \%)$ and the Bari Amerindians (22\%). The gene differentiation coefficient $\mathrm{G}_{\mathrm{ST}^{\prime}}$ indicates that the interpopulation variation is small. HT decomposition into its intra- and interpopulational components shows that the variability in the APOE locus is due to intrapopulational variation.

Frequency differences between Venezuelans and other populations are illustrated by genetic distances (DA) based on APOE frequencies (Table 3). As expected, a small genetic distance was found between Colonia Tovar and the population of Germany $(0.00142)$ indicating a high degree of relatedness. Very small distances are seen also between populations from Spain and Italy (0.0007) and between Mestizos from Mexico and Colombia. A similar trend is noticed between Venezuelan Mestizos and the population of Curiepe (0.00122) indicating gene flow. The native populations, Yucpa and Bari, are closer to each other (0.0110) than to the Cayapa (0.025 and 0.070). Surprinsingly the Wai Wai seem to be closer to the population of Nigeria (0.05627) and very distant to the Yucpa (0.3078) and the Bari (0.1898). This is probably due to the high prevalence of the APOE*4 allele in the Wai
Wai. In their past history the Wai Wai Indians of Brazil have had extensive intercrossing with groups that the Indians themselves distinguish as different [4].

In conclusion the frequencies of the APOE variants reflect ethnic differences existing between the Venezuelan communities and worldwide populations. This information will be very useful for future studies of APOE-disease associations in this country.

\section{References}

[1] F.M. Andrade, C.E.A. Coimbra., R.V. Santos, A. Goicoechea, F.R. Carnese, F.M. Salzano and M.H. Hutz, High heterogeneity of Apolipoprotein E gene frequencies in South American Indians, Annals of Human Biology 27 (2000), 29-34.

[2] M.C. Bortolini, T. De Azevedo Weimer, F.M. Salzano, S. Callegari-Jacques, H. Schneider, Z. Layrisse and S.L. Bonatto, Evolutionary relationships between Black South American and African Populations, Human Biology 67 (1995), 547559.

[3] D.A. Brouwer, H. Mulder, B. Fokkens, S. Ramsewak, F.A. Muskiet and D.D. Ramdath, Cord blood apolipoprotein-E genotype distribution and plasma lipid indices in newborns of different ethnicity, Annals of Human Biology 27 (2000), $367-375$.

[4] S.M. Callegari-Jacques, F.M. Salzano, T.A. Weimer, L.P. Franco, M.A. Mestriner, M.H. Hutz and L. Schüler, The Wai Wai Indians of South America: history and genetics, Annals of Human Biology 23 (1996), 189-201.

[5] E.H. Corder, A.M. Saunders, N.J. Risch, W.J. Strittmatter, D.E. Schmechel, P.C. Gaskel, J.B. Rimmler, P.A. Locke, P.M. Conneally, K.E. Schmader, G.W. Small, A.D. Roses, J.L. 
Haines and M.A. Pericack-Vance, Apolipoprotein E type 2 allele decreases the risk for late onset Alzheimer's disease, Nature Genetics 7 (1994), 180-184.

[6] D.E. Crews, M.I. Kamboh, J.J. Manchilha-Carvalho and B. Kottke, Population genetics of apolipoprotein A-4, E and $\mathrm{H}$ polymorphism in Yanomami Indians of north-western Brazil: Associations with lipids, lipoproteins and carbohydrate metabolism, Human Biology 65 (1993), 211-224.

[7] J. Davignon, R.E. Gregg and C.F. Sing, Apolipoprotein E polymorphism and atherosclerosis, Arteriosclerosis 8 (1988), $1-21$.

[8] M. Emi, L.L. Wu and M.A. Robertson et al., Genotyping and sequence analysis of apolipoprotein E isoforms, Genomics 3 (1988), 373-379.

[9] R. Gamboa, G. Hernández-Pacheco, R. Hesiquio, J. Zuñiga, F. Massó, L.F. Montaño, M. Ramos-Kuri, J. Estrada, J. Granados and G. Vargas-Alarcón, Apolipoprotein E Polymorphism in the Indian and Mestizo Populations of Mexico, Human Biology 72 (2000), 975-981.

[10] L.U. Gerdes, I.C. Klausen, I. Sihm and O. Faergeman, Apoliprotein E Polymorphism in a Danish Population Compared to Findings in 45 Other Study populations Around the World, Genetic Epidemiology 9 (1992), 157-167.

[11] L.U. Gerdes, C. Gerdes, P.S. Hansen, I.C. Klausen, O. Faergeman and J. Dyerberg, The apoliprotein E polymorphism in Greenland Inuit in its global perspective, Human Genetics $\mathbf{9 8}$ (1996), 546-550.

[12] J. Hixon and D. Vernier, Restriction isotyping of human apolipoprotein $\mathrm{E}$ by gene amplification and cleavage with HhaI, J Lipid Res 31 (1991), 545-548.

[13] J.P. Jaramillo-Correa, G. Keyeux, M. Ruíz-García, C. Rodas and J. Bernal, Population Genetic Analysis of the Genes APOE, APOB (3'VNTR) and ACE in Some Black and Amerindian Communities from Colombia, Hum Hered 52 (2001), 14-33.

[14] M.I. Kamboh, Apolipoprotein E polymorphism and susceptibility to Alzheimer's disease, Hum Biol 67 (1995), 195-215.

[15] S. Kataoka, D.C. Robbins, L.D. Cowan, O. Go, J.L. Yeh, R.B. Devereux, R.R. Fabsitz, E.T. Lee, T.K. Welty and B.V. Howard, Apolipoprotein E polymorphism in American Indians and its relation to plasma lipoproteins and diabetes, $A r$ teriosclerosis and Thrombosis Vascular Biology 16 (1996), 918-925.

[16] M. Layrisse and J. Wilbert, The Chibchan tribes, in: Indian Societies of Venezuela. Their Blood Group Types, M. Layrisse and J. Wilbert, eds, Editorial Sucre, Caracas, 1966, p. 161.

[17] C.L. Lendon, F. Ashall and A.M. Goate, Exploring the etiology of Alzheimer's disease using molecular genetics, Journal of the American Medical Association 277 (1997), 825-831.

[18] R.W. Mahley, T.L. Innerarity, S.C. Rall and K.H. Weisgraber, Plasma lipoproteins: apolipoprotein structure and function, $J$ Lipid Res 25 (1984), 1277-1294.

[19] R.W. Mahley, Apolipoprotein E: Cholesterol transport protein with expanding role in cell biology, Science 240 (1988), 622630.

[20] G.B. Marin, M.H. Tavella, J.F. Guerreiro, S.E.B. Santos and M.A. Zago, Absence of the $\mathrm{E}^{*} 2$ allele of apolipoprotein in Amerindians, Brazilian Journal Genetics 20 (1997), 741-743.
[21] S. Miller, D. Dykes and H.A. Polesky, A simple salting out procedure for extracting DNA from human nucleated cells, Nucleic Acids Res 16 (1988), 1215.

[22] A.E. Molero, G. Pino-Ramírez and G. Maestre, Modulation by age and gender of risk for Alzheimer's disease and vascular dementia associated with the apolipoprotein $\mathrm{E}-\varepsilon 4$ allele in Latin Americans: findings from the Maracaibo Aging Study, Neuroscience Letters 307 (2001), 5-8.

[23] M. Nei, Analysis of gene diversity in subdivided populations, Proc Natl Acad Sci USA 70 (1973), 3321-3323.

[24] M. Nei, Definition and estimation of fixation indices, Evolution 40 (1986), 643-645.

[25] M. Nei, Molecular evolutionary genetics, Columbia University Press, New York, 1987, p. 512.

[26] M. Nei, F. Tajima and Y. Tateno, Accuracy of estimated phylogenetic trees from molecular data, J Mol Evol 19 (1983), $153-170$.

[27] T. Ota, DISPAN: Genetic distance and phylogenetic analysis. Institute Molecular Evolutionary Genetics, The Pennsylvania State University, University Park, 1993.

[28] L. Pineda, J. Pinto-Cisternas and S. Arias, Consanguinity in Colonia Tovar, a Venezuelan isolate of German origin, J Hum Evol 14 (1985), 587-596.

[29] S. Rivera, J. Weir, M. Echeverria, G. Marquez, A. Fuenmayor, M. Hassanhi, M. Gomales, O. Balbas and Z. Layrisse, HLA en la poblacion zuliana de Venezuela, Inmunologia 17 (1998), 137-145.

[30] N. Saitou and M. Nei, The neighbor-joining method. A new method for reconstructing phylogenetic trees, Mol Biol Evol 4 (1987), 406-425.

[31] R. Scacchi, R.M. Corbo, O. Rickards, E. Mantuano, A. Guevara and G.F. De Stefano, Apolipoprotein B and E genetic polymorphisms in the Cayapa Indians of Ecuador, Human Biology 69 (1997), 375-382.

[32] F. Schachter, L. Faure-Delanef, F. Guenot, H. Rouger, P. Froguel, L. Lesueur-Ginot and D. Cohen, Genetic association with human longevity at the APOE and ACE loci, Nature Genet 6 (1994), 29-32.

[33] C.F. Sing and P.P. Moll, Genetics of variability of CHD risk, Int J Epidemiol 18(Suppl 1) (1989), S183-S195.

[34] C. Snowden, R.S. Houlston, M.H. Arif, M.F. Laker, S.E. Humphries and K.G.M.M. Alberti, Disparity between apolipoprotein E phenotypes and genotypes (as determined by polymerase chain reaction and oligonucleotide probes) in patients with non-insulin-dependent diabetes mellitus, Clin Chim Acta 196 (1991), 49-58.

[35] W.J. Strittmatter, A.M. Saunders and D. Schmechel, Apolipoprotein E: High affinity binding to $\beta$ A amyloid and increased frequency of type 4 allele in familial Alzheimer's disease, Proceedings of the National Academy of Sciences, USA 90 (1993), 1971-1987.

[36] G. Utermann, M. Hees and A. Steinmetz, Polymorphism of apolipoprotein $\mathrm{E}$ and occurrence of dysbetalipoproteinaemia in man, Nature 269 (1977), 604-607.

[37] G. Utermann, I. Kindermann, H. Kaffarnik and A. Steinmetz, Apolipoprotein E phenotypes and hyperlipidemia, Hum Genet 65 (1984), 232-236. 


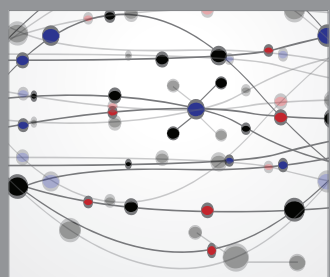

The Scientific World Journal
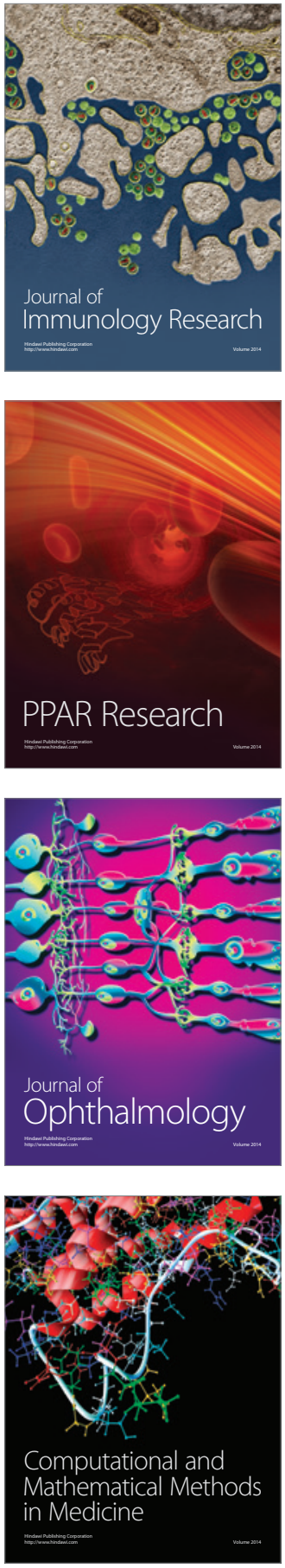

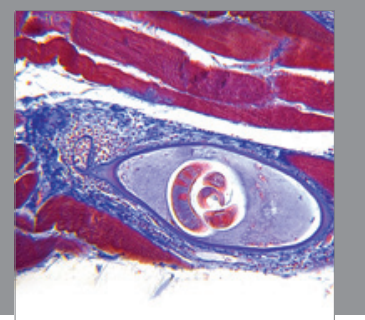

Gastroenterology

Research and Practice
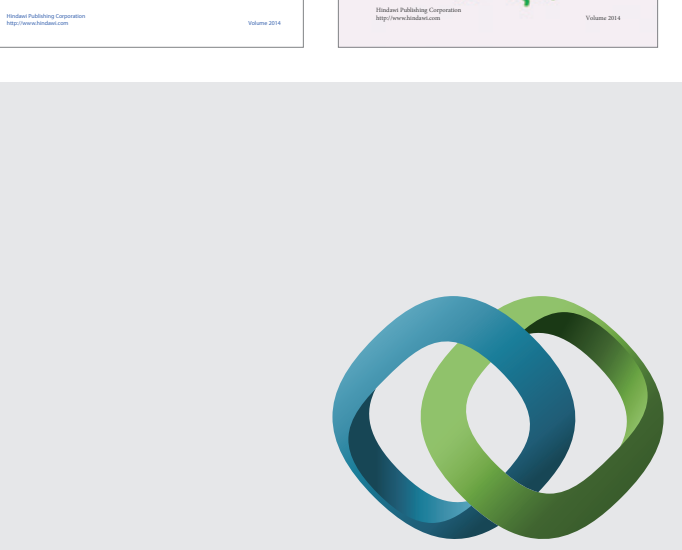

\section{Hindawi}

Submit your manuscripts at

http://www.hindawi.com
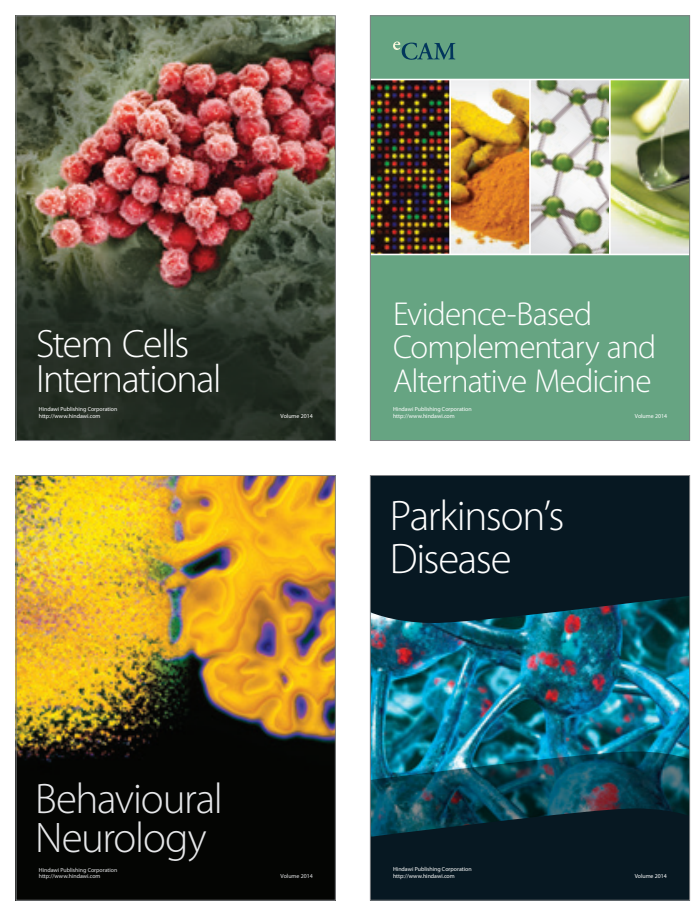

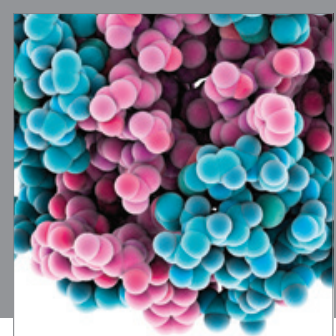

Journal of
Diabetes Research

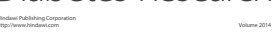

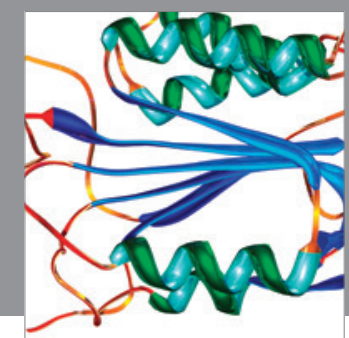

Disease Markers
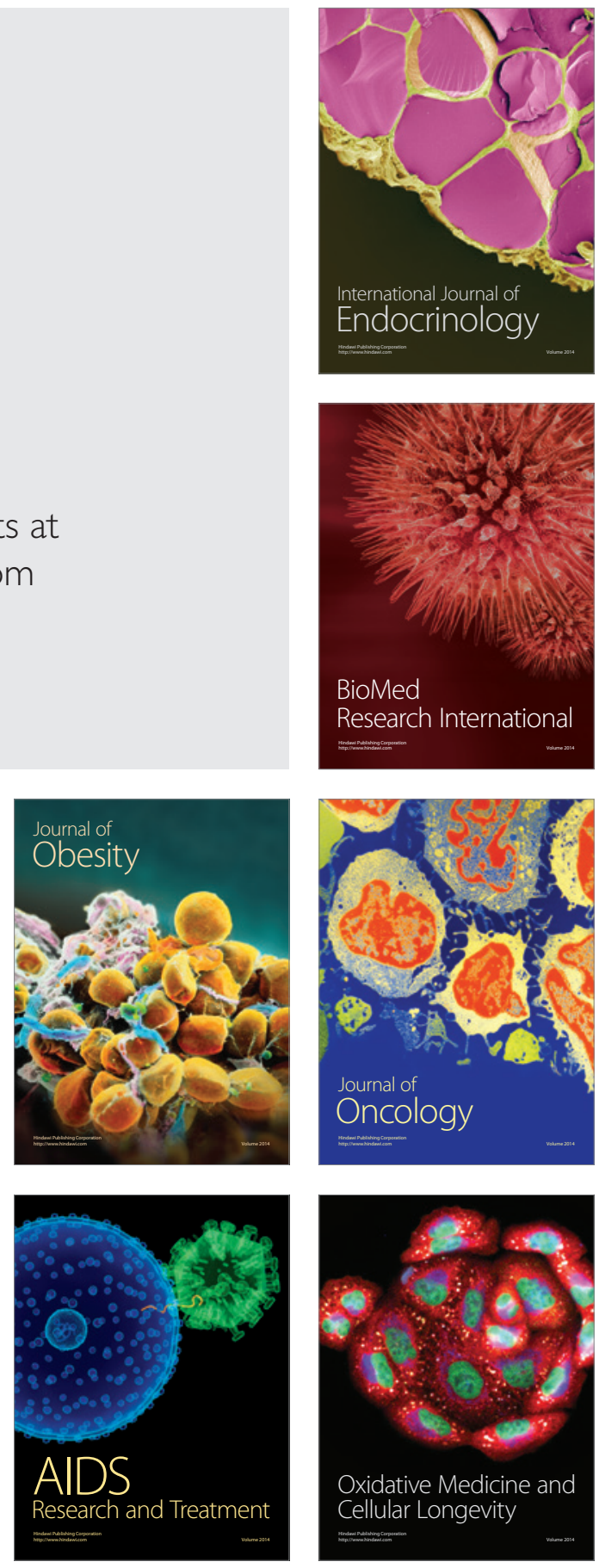